\title{
Use of history science methods in exposure assessment for occupational health studies
}

\author{
$\mathrm{K}$ Johansen, $\mathrm{H}$ Tinnerberg, E Lynge
}

Occup Environ Med 2005;62:434-441. doi: 10.1136/oem.2004.016493

See end of article for authors' affiliations

\section{Correspondence to:}

Ms K Johansen, Institute of Public Health, University of Copenhagen, Blegdamsvej 3, DK-2200 Copenhagen N, Denmark; k.johansen@ púbhealth.ku.dk

Accepted 1 December 2004
Aims: To show the power of history science methods for exposure assessment in occupational health studies, using the dry cleaning industry in Denmark around 1970 as the example.

Methods: Exposure data and other information on exposure status were searched for in unconventional data sources such as the Danish National Archives, the Danish Royal Library, archives of Statistics Denmark, the National Institute of Occupational Health, Denmark, and the Danish Labor Inspection Agency. Individual census forms were retrieved from the Danish National Archives.

Results: It was estimated that in total 3267 persons worked in the dry cleaning industry in Denmark in 1970. They typically worked in small shops with an average size of 3.5 persons. Of these, 2645 persons were considered exposed to solvents as they were dry cleaners or worked very close to the dry cleaning process, while 622 persons were office workers, drivers, etc in shops with 10 or more persons. It was estimated that tetrachloroethylene constituted $85 \%$ of the dry cleaning solvent used, and that a shop would normally have two machines using 4.6 tons of tetrachloroethylene annually.

Conclusion: The history science methods, including retrieval of material from the Danish National Archives and a thorough search in the Royal Library for publications on dry cleaning, turned out to be a very fruifful approach for collection of exposure data on dry cleaning work in Denmark. The history science methods proved to be a useful supplement to the exposure assessment methods normally applied in epidemiological studies.
$\mathrm{T}$ here is often a long latency time between an occupational exposure and its eventual negative health consequences. Suspicion of an association may therefore arise many years after the actual exposure took place. In the meantime, technologies and companies can have changed, which complicates exposure assessment. Historical cohort studies can be undertaken in situations where the exposure took place in relatively large companies still operating at the time of the disease occurrence, for example, the cohort study from the large nickel refinery in Norway. ${ }^{1}$ Where such cohort studies are not possible, exposure assessment has to rely on case-control studies with interviews of the subjects or the next-of-kin, for example, the study on exposure to phenoxy herbicides and soft tissue sarcoma from Sweden in the 1980s. ${ }^{2}$ The value of interview data is, however, limited by the lack of knowledge on past exposure among the subjects or the next-of-kin, the potential recall bias between cases and controls, and by the, nowadays, very low response rate, especially among controls. There is consequently a need in occupational health epidemiology for additional methods for collection of exposure data.

The purpose of this paper is to show, by use of the exposure to tetrachloroethylene among dry cleaners in Denmark as an example, the wealth of highly relevant data which may be available in historical archives.

Previous studies of dry cleaners, primarily from the USA, indicated that exposure to tetrachloroethylene may entail an increased risk of cancer of the oesophagus, of the cervix uteri, and of non-Hodgkin's lymphoma. ${ }^{3}$ Tetrachloroethylene has also been the dominant dry cleaning solvent in Denmark. However, "the average earnings of dry cleaners [in the USA] was about two-thirds that of average from private sector workers", and the excess risk of oesophageal cancer occurred primarily among black men. ${ }^{4}$ In Denmark, dry cleaning shops used to be small family businesses, ${ }^{5}$ indicating that the subjects in dry cleaning in Denmark belonged to a higher socioeconomic group than the dry cleaning workers in the USA. We are therefore investigating cancer in dry cleaners in Denmark to test whether the US findings can be reproduced in this other setting. Parallel studies are being undertaken in Norway, Sweden, and Finland. We needed here to identify people working in dry cleaning 30-40 years ago. We also wanted to know their length of employment, and exposure level at the time. In 2003, few of the previous owners of the small family dry cleaning shops would be available for interview, and we therefore developed a set of new methods for collection of exposure data.

\section{METHODS}

We wanted to study whether dry cleaning workers in Denmark had an increased risk of cancer of the oesophagus, cardia, liver, cervix uteri, bladder, and pancreas, and of renal cell carcinoma and non-Hodgkin's lymphoma. It was not possible to collect a cohort of dry cleaning workers in Denmark because this industry traditionally consisted of many small shops. We therefore used another approach. The 1970 census was available in a computerised form with a unique personal identification number (CPR number) for each citizen. Dry cleaners were, however, not given a separate code in the computerised file. Dry cleaners could only be identified as part of a larger group of persons having the industry code "laundry, dry cleaning, and dyeing" and/or the occupation code "laundry worker, ironer". We retrieved data for this cohort and then designed our study as a series of case-control studies nested in the cohort (fig l).

The CPR number of each cohort member was linked with the data in the Danish Cancer Register. In this way we identified cohort members diagnosed with cancer between the census date in 1970 and the end of 1999. These persons constituted the cases in our case-control study. After identification of the cases, we selected the controls from the cohort using incidence density sampling. We then had the cases and 


\section{Main messages}

- Use of history science methods proved to be a powerful tool in collection of occupational exposure data.

the controls, but we did still not know which of them had worked in dry cleaning. However, an archive search showed that the original 1970 census forms were stored in the Danish National Archives. These forms included a detailed free text on employment, job title, company name, and address. The free text enabled us to distinguish between the dry cleaners and the laundry workers. We retrieved the forms from the archive, and coded the job tasks according to the list shown in table 1 .

For cases and controls working in dry cleaning we also wanted to know the length of their employment at the workplace they had in 1970. For persons working in dry cleaning, but not specified as dry cleaners in the census forms, we furthermore wanted to know the number of people employed at their workplace in 1970. In order to search for data on these two variables, we split the dry cleaners between those being employees in 1970, and those being selfemployed persons or family workers, the latter group being spouses working in the family shop. For the group of employees, we used data from the supplementary pension scheme (ATP). Since 1964, all companies have paid annual contributions to this scheme for each of their employees. In the pension scheme data, an employee is identified by his/her CPR number, and a company is identified by an SE number. For each employee we search for the SE number paying this person's pension contribution in 1970. The length of an employee's employment in the company was then measured as the number of years around 1970 where the same SE number had paid the pension contribution. The supplementary pension scheme data were only available for our study from the start of 1964 until 1979. Our study was therefore restricted to this period. The number of employees in the 1970 workplace was calculated as the number of persons with pension scheme contributions paid by the given SE number in 1970.

The self-employed workers were the owners of the dry cleaning shops. They were not covered by the supplementary pension scheme (ATP). We therefore searched the Royal Library for literature on dry cleaning, and discovered a biographical registration of self-employed dry cleaning and laundry workers from 1971, "The Danish laundry and dry cleaning industry". ${ }^{6}$ It included names and addresses of dry cleaning shops, usually the number and type of dry cleaning machines, the names of the owners and usually their spouses, and the length of time they had been in operation. ${ }^{6}$ Self-employed and family workers not found in the biography book were searched for in local telephone books which typically included the name of the shop, the name of the owner, the address, and the telephone number. The period of interest was the years from 1964 to 1979 , as this period was covered by the supplementary pension scheme data for the employees. The length of employment after 1971 for those found in the biography book was also searched for in the telephone books. The length of employment for a selfemployed person was measured as the number of years in which he/she was listed as the owner. Family workers were assumed to have worked the same number of years as the owner of the shop. All telephone books are available in the Royal Library.

The detailed occupational codes combined with size of the company for the employees were used to distinguish

\section{Policy implications}

- The level of exposure to tetrachloroethylene in the dry cleaning industry has been lower in Denmark than in the USA.

between: (1) persons explicitly described as "dry cleaners", and workers with other job tasks in dry cleaning shops with less than 10 employees; the latter group was included due to the physical proximity and shared work tasks in these small shops; (2) "other workers" in dry cleaning shops with more than 10 employees, for example, office workers or drivers; and (3) unexposed, laundry workers (table 1). We searched reports on occupational poisoning from 1945 onwards in the archives of the Labor Inspection Agency, and in the weekly journal of the Danish Medical Association. Records on air measurements of tetrachloroethylene from dry cleaning shops were searched for in the National Institute of Occupational Health, Denmark. The records included date of investigation, name of shop, number and type of dry cleaning machines, a graphic outline of the shop, and details on the analytical method. In addition, the search on literature on dry cleaning in the Royal Library revealed a report from 1979-80 on measurements made by the Danish Technological Institute. $^{78}$

A literature search in the Royal Library showed that the Association of Dry Cleaning Shops had published journals; from 1944 to 1965, Renseriejeren, and from 1965 to 1995 , Nordisk tidsskrift for rensning farvning og vask. The journals provided a detailed picture of the development in machinery and dry cleaning solvents used, and a comparative study of the dry cleaning industry in 1968 in the USA, the UK, Denmark, Finland, and Sweden. All legal regulations on dry cleaning in Denmark from 1952 onwards were retrieved from the archive of the Danish Labor Inspection Agency. In Statistics Denmark, annual production and foreign trade statistics on tetrachloroethylene were available from 1945 onwards.

\section{RESULTS}

The identified data allowed a detailed recording of the technological development of the Danish dry cleaning industry, and assessment of exposure status for each case and control in our study. The recording of the technological development was necessary in order to determine when tetrachloroethylene started to be used in dry cleaning in Denmark, and to estimate the proportion of dry cleaning in Denmark undertaken with tetrachloroethylene at different points in time. We start therefore with a historical description.

\section{Dry cleaning industry in Denmark}

The founder of dry cleaning in Denmark, Georg E Mathiasen (GEM), introduced trichloroethylene as a dry cleaning solvent in the 1930s. ${ }^{6}$ The semi-automatic GEM machines could also use tetrachloroethylene, but the supply was limited in Denmark in the 1950s. ${ }^{9}$ These machines were unique because the clothes were both dry cleaned and dried in a one-step process which eliminated the manual transfer of wet clothes. In 1953, rules were set up for use of trichloroethylene and tetrachloroethylene requiring that machines were tight, in good repair, and mounted in separate rooms. The rules prohibited the staff from removing the clothes from the machine before they were completely dry. ${ }^{10}$

In 1959, the fully automated dry cleaning machines, the German "Zanker" and the English "Spencer", were introduced in Denmark after the post-war import regulations were 


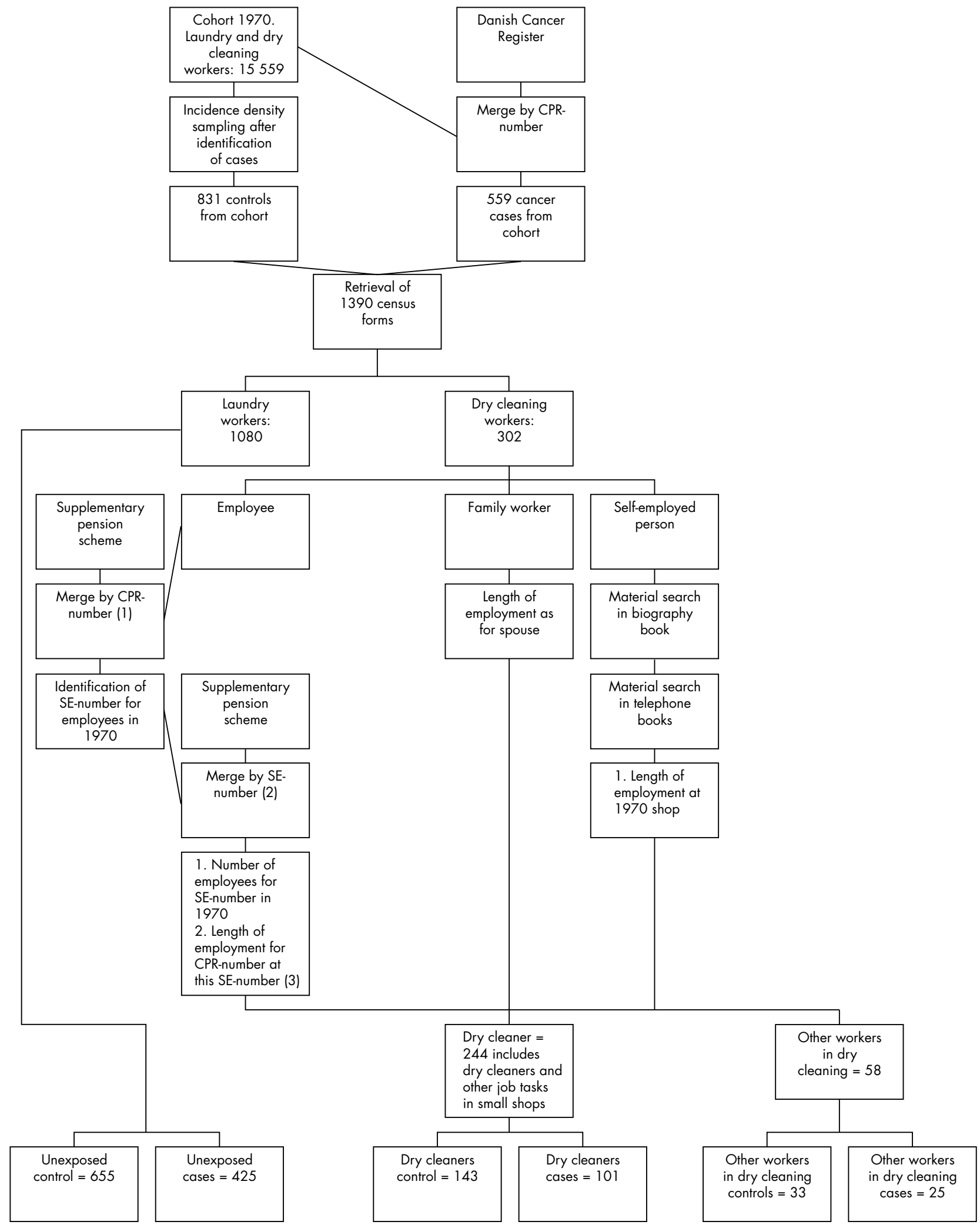

Figure 1 Design of Danish dry cleaner case-control study and assessment of exposure to tetrachloroethylene for cases and controls. (1) CPR number is a unique personal identification number. (2) SE number is a unique company number. (3) Number of employees for SE number was missing for 10 persons. We assumed the shops to be small based on information on the employers, such as number of machines listed in the biography book.

lifted. ${ }^{11}$ Both tetrachloroethylene and trichloroethylene could be used in the machines, but tetrachloroethylene worked better on the newly introduced synthetic fibres of cellulose triacetate; ${ }^{12}$ it was not that aggressive to the colours of the textile, was more harmless to cotton, and less volatile. ${ }^{13}$ The operation of the new machines was much simpler than the old GEM machines, and better centrifugation meant that less solvent was left in the clothes. ${ }^{12}$ This first generation of fully 
Table 1 Detailed job description and exposure status in 1970 for the 831 controls in the Danish dry cleaner study

\begin{tabular}{|c|c|c|c|c|c|}
\hline \multirow[b]{2}{*}{ Code } & \multirow[b]{2}{*}{ Detailed job description } & \multicolumn{3}{|c|}{ Size of workplace } & \multirow[b]{2}{*}{ Total } \\
\hline & & $<10$ & $\geqslant 10$ & Unknown & \\
\hline 010 & $\begin{array}{l}\text { Dry cleaner, incl. owner, manager of dry cleaning shop* } \\
\text { Other workers in dry cleaning }\end{array}$ & - & - & 55 & 89 \\
\hline 021 & Presser, ironer & 8 & 6 & 1 & 15 \\
\hline 022 & Spot cleaner & 0 & 2 & 1 & 3 \\
\hline 023 & Shop assistant, packing, sorting & 14 & 9 & 3 & 26 \\
\hline 024 & Accounting, office & 0 & 4 & 0 & 4 \\
\hline 025 & Driver & 5 & 2 & 2 & 9 \\
\hline 026 & Tailor/sewing & 0 & 0 & 1 & 1 \\
\hline 027 & Shop for collection/return of clothes for dry cleaning & 0 & 0 & 5 & 5 \\
\hline 030 & $\begin{array}{l}\text { Dry cleaner also doing laundry work, including owner, manager of } \\
\text { combined dry cleaning/laundry shop* } \\
\text { Other workers in dry cleaning/laundry }\end{array}$ & - & - & 9 & 15 \\
\hline 033 & Shop assistant, packing, sorting & 0 & 0 & 1 & 1 \\
\hline 040 & $\begin{array}{l}\text { Dry cleaner also doing dyeing work, including owner, manager of } \\
\text { combined dry cleaning/dye shop* } \\
\text { Other workers in dry cleaning/dye shop }\end{array}$ & - & - & 1 & 4 \\
\hline 041 & Presser, ironer & 1 & 0 & 0 & 1 \\
\hline 048 & Dyer & 2 & 0 & 1 & 3 \\
\hline 050 & Dye shop, all jobs & 0 & 0 & 5 & 5 \\
\hline 060 & Laundry hospital, all jobs & 0 & 0 & 59 & 59 \\
\hline 070 & Laundry not hospital, all jobs & 0 & 0 & 508 & 508 \\
\hline 080 & Textile industry, renting of clothes, ironer, etc & 0 & 0 & 55 & 55 \\
\hline 090 & Mangle shop & 0 & 0 & 19 & 19 \\
\hline \multirow[t]{5}{*}{100} & Census form incorrectly coded & 0 & 0 & 9 & 9 \\
\hline & Total & 55 & 41 & 735 & 831 \\
\hline & $\begin{array}{l}\text { Dry cleaner and other workers in dry cleaning shops with less than } 10 \\
\text { employees } t\end{array}$ & - & - & - & 143 \\
\hline & Other workers in dry cleaning shops $\ddagger$ & - & - & - & 33 \\
\hline & Unexposed workers being laundry workers, mangle shops owners, etc§ & - & - & - & 655 \\
\hline \multicolumn{6}{|c|}{$\begin{array}{l}\text { *Owners and managers of dry cleaning shops were all coded as "dry cleaners" due to the small average size of the shops, and the clear referral to them as active } \\
\text { workers in the dry cleaning association journals. } \\
+(\text { Code } 010,030,040) \text { and }((\text { code } 021-026,033,041,048) \text { and (size }<10)) \text {. } \\
\pm(\text { Code } 027+((c o d e 021-026,033,041,048) \text { and }(\text { size }>10))) \text {. The few persons with detailed occupational codes } 021-026,033,041,048 \text { and size unknown, } \\
\text { were individually allocated to the dry cleaner group or other workers group based on available information, e.g. number of machines in the shop. } \\
\S(\text { Code } 050-100) \text {. A mangle shop was a shop where cold ironing of linen was performed after washing. }\end{array}$} \\
\hline
\end{tabular}

automated dry-to-dry machines were open circuit machines-that is, at the end of the drying process a ventilating duct for residual volatilised solvent was opened to the atmosphere.

In 1964, the rules for dry cleaning machines using tetrachloroethylene were revised. Machines did not have to be mounted in separate rooms any more as long as the front of the machine was separated from the back with a wall. Dry cleaning was only permitted in automated dry-to-dry machines and the machines had to be constructed in such a way that they could not start before the doors were closed and the ventilation started. A closed system for solvent filling and sump removal was made compulsory, and all solvents had to be kept in closed containers. ${ }^{14}$ In the 1960s, the structure of the Danish dry cleaning sector was very heterogeneous. Many new dry cleaning shops started with self-service coin operated machines and no pre- or aftertreatment of the clothes. In conventional shops, the clothes were spot cleaned before the dry cleaning and ironed, pressed, and steamed afterwards. ${ }^{15}$ In 1968, 40\% of all dry cleaned clothes in Denmark were cleaned in coin operated machines, and all coin operated machines were loaded with tetrachloroethylene. ${ }^{16}$ In 1967, about 30\% of conventional shops had machines obtained within the last 10 years, whereas $30-50 \%$ of the machines were $20-30$ years old. ${ }^{17}$ Old machinery was likely to have a higher exposure due to equipment wear, corrosion, or inadequate maintenance. A very few shops specialising in cleaning of working clothes were still using trichloroethylene. ${ }^{18}$ Three quarters of the dry cleaning in Denmark was undertaken in small shops, and tetrachloroethylene constituted about $70-75 \%$ of the solvents used (table 2). ${ }^{16}$ In 1971, tetrachloroethylene constituted $90 \%$ of the solvents used in Scandinavia. ${ }^{18}$ Other solvents in use were white spirit and chlorofluorocarbons.

The total annual consumption of tetrachloroethylene rose from 900 tons in 1959 to a maximum of about 5500 in 1970, and then decreased to the present level of about 300 tons $^{19-21}$ (fig 2). In the 1970s, 93\% of the tetrachloroethylene in Denmark was used for dry cleaning. ${ }^{22}$ The decline in use was due to fashion changes to water-washable clothes. ${ }^{8}$ In 1968, Denmark had $4 \mathrm{~kg}$ of dry cleaned clothes per person, in total 19421 tons, $^{16}$ which had declined to 7250 tons in 1987.. ${ }^{23}$ Rising environmental awareness and increasing prices also promoted lower consumption. Furthermore, in 1978 the first closed circuit machine was introduced. ${ }^{24}$ This non-vented dry-to-dry machine with a refrigerated condenser was only opened to the atmosphere when the machine door was opened. It allowed a more efficient solvent recovery and had a lower solvent emission compared to the open circuit machines. ${ }^{25} 26$ In the 1970s chlorofluorocarbons (CFCs) came on the market, constituting 30\% of the consumption in 1987. ${ }^{23}$ But new CFC machines were prohibited in 1992, and the ban on selling CFCs to the dry cleaning industry came into force in 1995. ${ }^{25}{ }^{27}$ In 1957, the permissible exposure limit for tetrachloroethylene was $350 \mathrm{mg} / \mathrm{m}^{3}$ (50 ppm), in 1975 it was lowered to $200 \mathrm{mg} / \mathrm{m}^{3}(30 \mathrm{ppm}){ }^{28}$ and in 1995 it was lowered to the present level of $70 \mathrm{mg} / \mathrm{m}^{3}(10 \mathrm{ppm}){ }^{25} 29$ In 1962, one case of tetrachloroethylene poisoning was reported to the Labor Inspection Agency. A dry cleaner fainted as she was spot cleaning with tetrachloroethylene outside the shop..$^{30}$ The medical journal reported six cases of poisoning in the 1970s, all among customers using coin operated machines. ${ }^{31}$ A Danish Technological Institute consultant reported in 1982 that it was very common among dry 


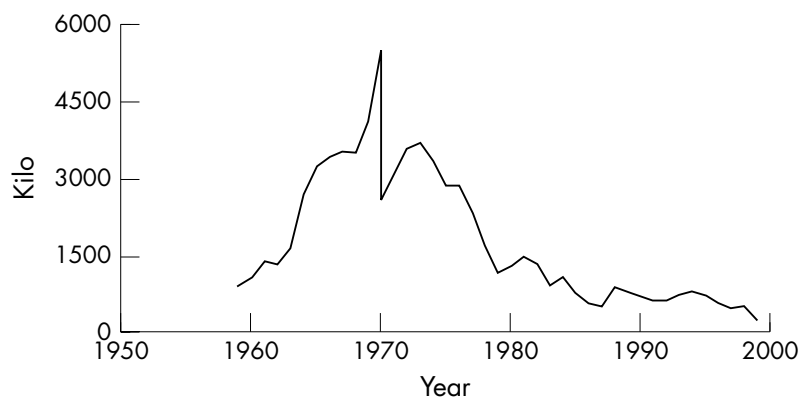

Figure 2 Consumption of tetrachloroethylene in Denmark from 1959 to 2000. Adding the production and import figures and subtracting the export figures identified the annual consumption of tetrachloroethylene. ${ }^{19-21}$

cleaners to smell the textile to determine the adequacy of the drying. ${ }^{7}$

A total of 348 tetrachloroethylene measurements in dry cleaning shops were performed in Denmark between 1947 and 1987 by the National Institute of Occupational Health. As several of the samples were consecutive short term samples, the number of independent observations was 86 (see table 3). Our case-control study covered the period 1964 to 1979. Only 31 measurements from 14 shops were available from this period. These measurements were made in 1964, 1965, 1967, 1969, and 1979, respectively. There was no clear trend in these data, although the 1979 measurement from a single shop was clearly below those from earlier years. A total of 67 measurements were made in $1979-80$ by the Danish Technological Institute. These measurements were also below those from the 1960s. As Danish measurement data were missing for most of the 1970s, we used the merged Nordic measurement data to get a better picture of the development during the period 1964 to 1979 . Only 107 Nordic measurements were available from 1964 to 1976, and only 45 of these had a sampling time longer than 60 minutes; of these, only 16 were personal samples. These sparse exposure data indicated a fairly constant median exposure level to tetrachloroethylene, just below $200 \mathrm{mg} / \mathrm{m}^{3}$. This does not imply that the exposure was constant during the working day in the shop. ${ }^{32}$ Exposure increased towards the end of the dry cleaning process, and a common practice of sniffing to the dried clothes also contributed to variation in exposure during the working day. From 1976 onwards more measurements were available and a decreasing trend was observed (Håkan Tinnerberg, personal communication, 2004).

\section{Individual exposure status}

The evaluation of each subject's exposure status was undertaken as a stepwise procedure as illustrated in fig 1 . The cohort of laundry and dry cleaning workers from the 1970 census included 15559 persons (3689 men and 11870 women). A total of 559 cancer cases were identified, and 831 controls were selected. The free text on the census forms showed that 655 controls did not work in dry cleaning shops. They were coded as unexposed. The remaining 176 controls worked in dry cleaning shops; they were split into two groups, "dry cleaners" and persons with other job tasks. Persons with other job tasks from small shops were grouped together with the dry cleaners, while persons with other job tasks from larger shops formed a separate group of "other workers". The dry cleaner group included 89 persons who stated themselves as dry cleaners (code 010), 15 with combined dry cleaning and laundry shops (code 030), and four with combined dry cleaning and dye shops (code 040). These 108 controls were all classified as "dry cleaners". Five controls worked only with collection/returning of dry cleaned clothes; they were classified as "other workers" since dry cleaning and pressing were not performed in the shop. The remaining 63 controls from dry cleaning shops had other job tasks. Of these, 30 worked in shops with less than 10 employees and were classified as "dry cleaners" due to the physical proximity and shared worked tasks in these small shops; 23 worked in larger shops and were classified as "other workers". Size of workplace was unknown for the remaining 10 controls, but they were individually allocated to the "dry cleaner" or "other worker" group based on, for example, number of machines in the shop. We ended up with 143 controls classified as "dry cleaners" in 1970 (table 1). As $75 \%$ of the dry cleaning solvent used in Denmark in 1968 was tetrachloroethylene, ${ }^{16}$ and this percentage had increased to $90 \%$ in $1971,^{18}$ we estimated that tetrachloroethylene constituted $85 \%$ of the dry cleaning solvent used in 1970. It is reasonable therefore to conclude that by far the majority of the 143 "dry cleaners" were exposed to tetrachloroethylene.

The duration of employment could be assessed for $93 \%$ of the controls in dry cleaning shops $(=163 / 176)$ (table 4$)$.

We used the data from the 1970 census cohort of laundry and dry cleaning workers and the exposure status data for the 831 controls to estimate the total number of persons working in dry cleaning in Denmark in 1970. This extrapolation gave 3267 persons worked in dry cleaning in Denmark in 1970, of which 2645 were considered exposed to solvents as they were dry cleaners or worked very close to the dry cleaning process, while 622 persons were office workers, drivers, etc in shops with 10 or more persons (table 5). With the estimated numbers of 3267 persons working in dry cleaning and 932 dry cleaning shops, on average 3.5 persons worked in each shop. This shows that by far the majority of the dry cleaning shops were small family shops. According to the book "The Danish Laundry and Dry Cleaning Industry 1971", each shop had on average two machines, giving in total 1865 machines. The daily capacity of a shop operating two machines was $80 \mathrm{~kg}$ of clothes. In total, 3885 tons of tetrachloroethylene were used in Denmark in 1970, of which $93 \%$ were in dry cleaning. Consequently, the estimated consumption of tetrachloroethylene in a dry cleaning shop

Table 2 International comparison of dry cleaning industry in $1968^{16}$

\begin{tabular}{|c|c|c|c|c|c|c|c|c|}
\hline \multirow[b]{2}{*}{ Country } & \multirow{2}{*}{$\begin{array}{l}\text { Dry cleaned } \\
\text { clothes }(\mathrm{kg} / \\
\text { person) }\end{array}$} & \multirow{2}{*}{$\begin{array}{l}\% \text { self-service of } \\
\text { total amount of } \\
\text { clothes }\end{array}$} & \multirow{2}{*}{$\begin{array}{l}\text { \% clothes cleaned } \\
\text { in shops cleaning } \\
<50000 \mathrm{~kg}\end{array}$} & \multicolumn{5}{|c|}{ Solvents used, $\%$ of total } \\
\hline & & & & $\begin{array}{l}\text { Tetrachloro- } \\
\text { ethylene }\end{array}$ & $\begin{array}{l}\text { Trichloro- } \\
\text { ethylene }\end{array}$ & White spirit & $\begin{array}{l}\text { Chlorofluoro- } \\
\text { carbons }\end{array}$ & $\begin{array}{l}\text { Water based } \\
\text { cleaning }\end{array}$ \\
\hline USA & 7.65 & 2 & - & 50 & - & 50 & $<1$ & - \\
\hline UK & 3.5 & 0.5 & 11 & 84 & - & 14 & 1 & 2 \\
\hline Denmark & 4 & 40 & 70 & 75 & 4 & 20 & 1 & - \\
\hline Finland & 1 & 27 & 49 & 85 & 8 & 0.5 & 0.8 & 5.5 \\
\hline Sweden & 1.25 & 45 & 75 & 71.5 & 0.5 & 4 & 8.5 & 15 \\
\hline
\end{tabular}

The analysis was based on questionnaires made by the English Research Institute for Dry Cleaning (DCRO) and the International Dry Cleaning Association (CITEN) in 1968. 
Table 3 Measurements of tetrachloroethylene in dry cleaning plants in Denmark

\begin{tabular}{|c|c|c|c|c|c|c|c|}
\hline \multirow[b]{2}{*}{ Year } & \multirow[b]{2}{*}{ No. of plants } & \multirow[b]{2}{*}{$\begin{array}{l}\text { No. of } \\
\text { observations }\end{array}$} & \multicolumn{5}{|c|}{ Air concentration $\left(\mathrm{mg} / \mathrm{m}^{3}\right)$} \\
\hline & & & Min & $\operatorname{Max}$ & $\begin{array}{l}\text { Time weighted } \\
\text { mean }\end{array}$ & $\begin{array}{l}\text { Geometric } \\
\text { mean }\end{array}$ & GSD \\
\hline \multicolumn{8}{|c|}{ National Institute of Occupational Health, Denmark } \\
\hline 1947 & 1 & 1 & - & 300 & - & - & - \\
\hline 1949 & 1 & 1 & - & 510 & - & - & - \\
\hline 1956 & 1 & 1 & - & 130 & - & - & - \\
\hline 1962 & 1 & 3 & 70 & 898 & 553 & 351 & 4.5 \\
\hline 1963 & $12^{*}$ & 27 & 10 & 1150 & 227 & 98 & 5.1 \\
\hline 1964 & $5^{*}$ & 10 & 30 & 875 & 271 & 148 & 41 \\
\hline 1965 & 4 & 8 & 0 & 7510 & 1218 & 169 & 28 \\
\hline 1967 & 2 & 3 & 100 & 370 & 200 & 169 & 2.1 \\
\hline 1969 & 2 & 3 & 485 & 4380 & 1823 & 1086 & 3.9 \\
\hline 1979 & 1 & 7 & 22 & 190 & 69 & 51 & 2.5 \\
\hline 1980 & 1 & 4 & 32 & 554 & 232 & 136 & 4.1 \\
\hline 1983 & 1 & 1 & - & 211 & - & - & - \\
\hline 1984 & 2 & 4 & 31 & 285 & 174 & 125 & 3.1 \\
\hline 1985 & 1 & 5 & 124 & 618 & 267 & 223 & 1.9 \\
\hline 1986 & 1 & 2 & 35 & 71 & - & - & - \\
\hline 1987 & 1 & 6 & 7 & 31 & 18 & 16 & 1.7 \\
\hline Total & 37 & 86 & & & & & \\
\hline \multicolumn{8}{|c|}{ Danish Technological Institute } \\
\hline $1979-\varepsilon$ & NR & 67 & - & 688 & 60 & $-\dagger$ & - \\
\hline
\end{tabular}

*The majority in coin operated dry cleaning shops.

tCannot be calculated from original data.

in Denmark in 1970 was 4.6 tons. In 1970, the dominant type of dry cleaning machine was an open circuit machine, where solvent emission into the air represents $90 \%$ of the solvent consumption. ${ }^{33}$ It is possible to use the production figures to give an estimate of the level of exposure to tetrachloroethylene in the dry cleaning shops. The measurement reports performed by the National Institute of Occupational Health in the 1960s showed that the shops were relatively small, between $40 \mathrm{~m}^{3}$ and $300 \mathrm{~m}^{3}$. The air exchange rate was in the range of 3-30 per hour. In 1982, correctly dried clothes contained solvent equivalent to $0.5 \%$ of the weight. ${ }^{7}$ A shop with a daily capacity of $80 \mathrm{~kg}$, a room volume of $100 \mathrm{~m}^{3}$, and an air exchange rate of 5 per hour, will then have had an exposure of $100 \mathrm{mg} / \mathrm{m}^{3}$ on the assumption that the solvent was spread immediately to the entire working room. However, from the National Institute of Occupational Health's survey we know that several of the shops were housed in basements with bad ventilation, far from all clothes were dried correctly, and emission from cage, gaskets, and pipe fittings went into the working rooms depending on the maintenance. $^{7}$ The actual exposure level might therefore have been above the estimated $100 \mathrm{mg} / \mathrm{m}^{3}$. The $100 \mathrm{mg} / \mathrm{m}^{3}$ estimated solely from the production figures with all its uncertainties is convincingly close to the exposure level just below $200 \mathrm{mg} / \mathrm{m}^{3}$ found in the joint Nordic data set of measurements. These two independent data sources therefore point to an exposure level in the order of $100-200 \mathrm{mg} / \mathrm{m}^{3}$.

\section{DISCUSSION}

In a recent review of the epidemiology on the carcinogenicity of tetrachloroethylene, Mundt et al concluded that there was a widespread lack of literature with valid exposure data. ${ }^{34} \mathrm{~A}$ major critique was that many studies included subjects not exposed to tetrachloroethylene, for example, laundry workers. Also the widespread lack of information regarding duration of exposure in many of the papers was criticised.

We used history science methods to collect these exposure data for Danish dry cleaners. In particular, the Danish National Archives and the Danish Royal Library were very good sources for information. The original census forms found in the National Archives made it possible to determine exactly who was a dry cleaner and who was a laundry worker in 1970. Length of exposure, a variable also missing in previous studies, could be assessed by use of a combination of historical data sources: supplementary pension scheme data, biography book, and telephone books. The same was true for size of workplace which could be assessed from the supplementary pension scheme data.

The detailed search of historical records revealed exposure data of decisive importance for comparison of our study results with those from, for example, US studies. It turned

Table 4 Dry cleaners and other workers in dry cleaning shops by length of employment

\begin{tabular}{|c|c|c|c|c|c|c|c|}
\hline \multirow[b]{2}{*}{ Data source } & \multicolumn{5}{|c|}{ Length of employment } & \multirow[b]{2}{*}{ Total } & \multirow[b]{2}{*}{ Total \% } \\
\hline & $1-4 y$ & $5-9 y$ & $10-14 y$ & $15 y+$ & Unknown* & & \\
\hline Pension scheme† & 24 & 45 & 10 & 3 & - & 82 & 47 \\
\hline Biography bookf & 0 & 9 & 8 & 17 & - & 34 & 19 \\
\hline Telephone book & 1 & 11 & 24 & 11 & - & 47 & 27 \\
\hline Only 1970 census & - & - & - & - & 13 & 13 & 7 \\
\hline Total & 25 & 65 & 42 & 31 & 13 & 176 & 100 \\
\hline Total \% & 14 & 37 & 24 & 18 & 7 & 176 & 100 \\
\hline
\end{tabular}

*We know from the census forms that these people worked in a dry cleaning shop in 1970.

†Possible years of registration 1964-79, see text.

†Hammershøy E. [The Danish Laundry and Dry Cleaning Industry]. Copenhagen: Forlaget Lieber, 1971. After 1971 the 34 persons were looked up in the telephone books as well. 
out, for instance, that the open transfer dry cleaning machines in which the operator moved solvent-wet clothes manually to the dryer had been prohibited in Denmark since 1953. In the USA, one third of the plants still used the open transfer process in $1971 .{ }^{34}$ Consequently, the potential for exposure via skin contact has been diminutive in Denmark compared with the USA. From the historical records we estimated the mean exposure to tetrachloroethylene to be somewhere between $100 \mathrm{mg} / \mathrm{m}^{3}$ and $200 \mathrm{mg} / \mathrm{m}^{3}$ in a typical dry cleaning shop in 1970. The exposure limit was $350 \mathrm{mg} / \mathrm{m}^{3}$ in 1970. In the mid and late 1970s, there was a rising national debate about tetrachloroethylene, ${ }^{35}$ and the exposure limit was lowered to $200 \mathrm{mg} / \mathrm{m}^{3}$. Better safety techniques were also implemented, and the exposure limit was reduced to $70 \mathrm{mg} / \mathrm{m}^{3}$ in 1995. In the USA, the current exposure limit is $678 \mathrm{mg} / \mathrm{m}^{3}$, and the American Conference of Governmental Industrial Hygienists recommends a TLV of $170 \mathrm{mg} / \mathrm{m}^{3} .^{36}$ Based on these comparisons, it seems likely that the past and current US levels of exposure to tetrachloroethylene were higher than the Danish levels.

Our estimates for consumption of tetrachloroethylene in the dry cleaning industry and in the individual shops in Denmark in 1970 are in accordance with figures from other independent sources. In 1995, the Danish Environmental Protection Agency studied six dry cleaning shops in order to identify better technology solutions. ${ }^{25}$ A shop with two open circuit Böwe maxima, R18S and R18E, dry cleaning machines from 1973 had an annual consumption of $4530 \mathrm{~kg}$ tetrachloroethylene, a number very close to our estimated 4.6 tons. In 1975, the Danish Technological Institute estimated that the average consumption of solvents was not below $18 \%$ of the weight of the dry cleaned clothes. In 1970, the amount of dry cleaned clothes was 19421 tons, which means that the total consumption of tetrachloroethylene in 1970 should then be 3496 tons. This number is also close to our estimated consumption of 3613 tons. We find it reassuring that our estimates in these two examples are well matched with data from other sources.

We estimated that tetrachloroethylene constituted $85 \%$ of the dry cleaning solvent used in 1970. It is reasonable therefore to conclude that "dry cleaners" in Denmark in 1970 were exposed to tetrachloroethylene. Due to the limitation in the pension scheme data we could only follow the employment of our cases and controls from 1964 to 1979. This was, however, not a major limitation as the period coincided with the boom in use of dry cleaning in Denmark around 1970. Danish air measurements data were lacking from the 1970s. We therefore used the joint Nordic air measurements data to assess the exposure level. These sparse data indicated fairly stable median exposure level just below $200 \mathrm{mg} / \mathrm{m}^{3}$ throughout the period 1964 to 1976. More measurements were available after 1976 and a decreasing exposure level was seen. In Danish data, very few of the cases and controls recruited from the 1970 census were still employed in dry cleaning in the late 1970s. Furthermore, the new closed circuit machines were not introduced in Denmark until the end of 1978. Based on these considerations we decided in the analysis to assume the exposure level to be constant from 1964 to 1979 .

In occupational health epidemiology we usually do not search for literature outside the "Medline world", but our study showed that it can be useful for historical cohort studies to search for information on exposure data in a broader range of different databases. In the present study the data from the Danish National Archives and from the Royal Library turned out to be highly valuable.

In conclusion, by using a history science approach it was possible to collect exposure data for a study on cancer risk in dry cleaners, despite the fact that these persons worked more than 30 years ago in small shops scattered throughout the country. Today many of these persons are dead and many of the shops are closed. We have thus shown that the combined use of historical archive data can be a powerful substitute

Table 5 Estimated picture of the Danish dry cleaning sector around 1970

\begin{tabular}{|c|c|c|}
\hline & What we know & What we estimate \\
\hline 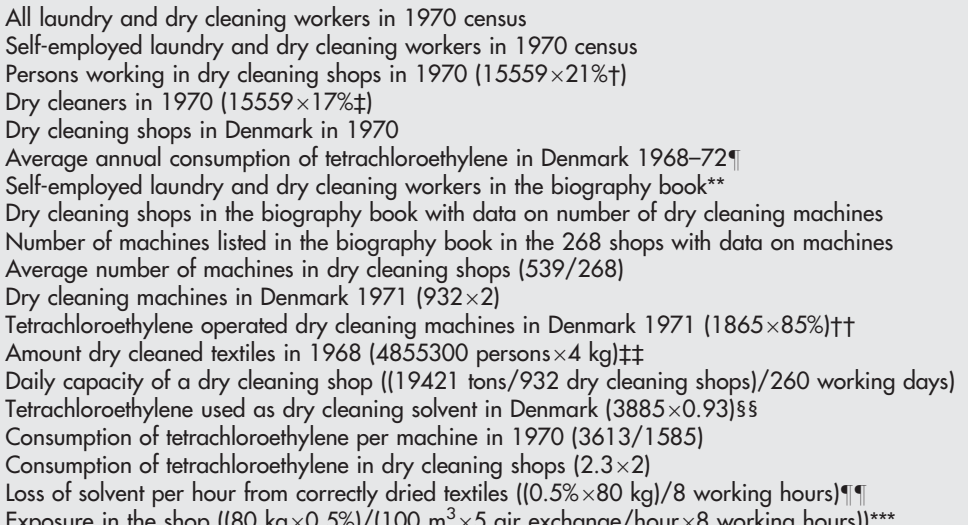 & $\begin{array}{l}3885 \text { tons } \\
1012 \text { persons } \\
268 \text { persons } \\
539 \text { machines }\end{array}$ & $\begin{array}{l}2 \text { machines } \\
1865 \text { machines } \\
1585 \text { machines } \\
19421 \text { tons } \\
80 \mathrm{~kg} \\
3613 \text { tons } \\
2.3 \text { tons } \\
4.6 \text { tons } \\
50 \mathrm{~g} \\
100 \mathrm{mg} / \mathrm{m}^{3}\end{array}$ \\
\hline
\end{tabular}

*This number is close to the number of 2886 VAT registered companies in laundry and dry cleaning in $1970 .{ }^{39}$

†Estimated from controls (table 1) $(143 / 655)=21 \%$.

†Estimated from controls (table 1) $(143 / 831)=17 \%$.

$\S(1556$ (self-employed in cohort) $\times 48 \%(\%$ dry cleaners in male controls) $)+(1030$ (self-employed women in cohort) $\times 18 \%(\%$ dry cleaners in female controls $))$. This number is higher than the unpublished number of 695 VAT registered companies in dry cleaning in $1970 .{ }^{5}$ It should be noted, however, that the industry code in the VAT register is not a quality checked and updated variable.

- Statistics Denmark $(1968=3521,1969=4161.5 \mathrm{t}, 1970=5553.9 \mathrm{t}, 1971=2567.1 \mathrm{t}, 1972=3621.7 \mathrm{t})$.

**Source: Hammershøy.

t†We estimate that tetrachloroethylene constituted $85 \%$ of the dry cleaning solvents used in 1970 , as it was $75 \%$ in $1968^{16}$ and $90 \%$ in $1971 .^{18}$

$\ddagger \ddagger 4855300$ persons lived in Denmark in 1970. From the 1968 dry cleaning industry data we know that the amount of dry cleaned clothes was $4 \mathrm{~kg} /$ person/y. $\S \S 93 \%$ of the consumption of tetrachloroethylene was used in dry cleaning. ${ }^{22}$

- Correctly dried clothes contained solvent equivalent to $0.5 \%$ of the weight. ${ }^{7}$

***The air measurements from the National Institute of Occupational Health included geographic outlines of the shops; $100 \mathrm{~m}^{3}$ was the average size of a Danish dry cleaning shop. 
when the classic historical cohort study from a large factory is not feasible. We have previously used similar methods for collection of exposure data for stone cutters ${ }^{37}$ and styrene exposed workers. ${ }^{38}$ The history science approach is clearly preferable to traditional case-control studies with recall problems and low response rates.

\section{ACKNOWLEDGEMENTS}

We are indebted to Inger Johansen, Danish Institute of Occupational Health, for information about the measurements made by the Institute.

\section{Authors' affiliations}

K Johansen, E Lynge, Institute of Public Health, University of Copenhagen, Denmark

H Tinnerberg, Department of Occupational and Environmental Medicine, Lund University, Sweden

Funding: this study was supported by the Danish Medical Research Council and The Halogenated Solvents Industry Alliance, Inc.

Competing interests: none declared

\section{REFERENCES}

1 Grimsrud TK, Berge SR, Martinsen Jl, et al. Lung cancer incidence among Norwegian nickel-refinery workers 1953-2000. J Environ Monit 2003;5:190-7.

2 Eriksson M, Hardell L, Berg NO, et al. Soft-tissue sarcomas and exposure to chemical substances: a case-referent study. $\mathrm{Br} J$ Ind Med 1981;38:27-33.

3 International Agency for Research on Cancer (IARC). Dry cleaning, some chlorinated solvents and other industrial chemicals, Vol 63. Lyon: IARC, 1995.

4 Blair A, Petralia SA, Stewart PA. Extended mortality follow-up of a cohort of dry cleaners. Ann Epidemiol 2003;13:50-6.

5 Lynge $E$, Thygesen L. Primary liver cancer among women in laundry and dry cleaning work in Denmark. Scand J Work Environ Health 1990;16:108-12.

6 Hammershøy E. De danske vaskeri- og renserierhverv. Faglig biografisk håndbog for de erhvervsdrivende inden for vaskeri- og renserierhvervene i Danmark [The Danish Laundry and Dry Cleaning Industry]. Copenhagen: Forlaget Lieber, 1971.

7 Ingvorsen C. Tørreproblemer og væsketab i renserier [Drying problems and loss of solvents in dry cleaning shops]. Tåstrup: Teknologisk Instituts Forlag, 1982.

8 Teknologisk Institut. Renserirapport 1977-1978 [Dry Cleaning Report 19771978]. Tåstrup: Teknologisk Instituts Forlag, 1978.

9 Anon. Blanding af tri og per [Mixing tri and per]. Renseriejeren $1951 ; 8$ (July):49-51.

10 Arbejds- og Fabriktilsynet. Regler for kemiske tøirenserier, der anvender triklorætylen (tri), tetraklorætylen = perklorætylen (per) eller ligende sundhedsfarlige rensemidler [Rules for dry cleaning shops using trichloroethylene, tetrachloroethylene or similar dangerous solvents] 1953.

11 Direktoratet for Arbejdstilsynet. Tillæg til R85/1953. Angår: Renseanlæg (rensemaskine) af englesk fabrikat "Spencer", model "Senior" og "Junior" for perklorætylen. [Dry cleaning machine from "Spencer", model "Senior" or "Junior" to tetrachloroethylene] 1959.

12 Rostell O. Fuldautomatisk tøirensning [Full automatic dry cleaning] Renseriejeren 1958;15(May):56-60.

13 Ingvorsen C. Renserimaskiner og deres virkemåde-Erhvervets teknologi [Dry cleaning machines and their functioning]. Copenhagen: Forlaget Liber, 1971:149-50.

14 Direktoratet for Arbejdstilsynet. Om regler for kemiske tøjrenserier, der anvender perklorætylen (per) og triklorætylen (tri) som renservæske [Rules for dry cleaning shops using tetrachloroethylene and trichloroethylene as dry cleaning solvent]. Meddelelse 1964;7.

15 Schleisner J. Dansk renserierhverv i året 1962 [Danish dry cleaning sector in the year 1962]. Renseriejeren 1963;20(Jan):1-2.

16 Anon. Strukturforhold og arbejdsteknik indenfor kemisk rensning i andre lande. [Structure and working skill in dry cleaning in other countries], Nordisk Tidsskrift for Rensning, Farvning og Vask, 1968;80(Feb):21-6.

17 Schleisner J. Er de konventionelle renseriers maskinpark tidsvarende? [Are the conventional dry cleaning machines up-to-date?]. Nordisk Tidsskrift for Rensning, Farvning og Vask 1967;79(May):8-9.

18 Anon. Moderne rensevæsker staves: PER og TRI, -men [How to spell modern solvents: Perchloroethylene and tricholorethylene]. Nordisk Tidsskrift for Rensning, Farvning og Vask 1971;83(July):16-19.

$19 \mathrm{http}: / /$ www. statistikbanken.dk Statistics for the Danish populations, 2004

20 Danmarks Statistik. Varestatistik for Industri 1999 [Manufacturers' sales of commodities 1999], And all previous publications. Copenhagen: Danmarks Statistik, 2000

21 Danmarks Statistik. Udenrigshandelen fordelt på varer og lande 1999 [External trade by commodities and countries 1999], And all previous publications. Copenhagen: Danmarks Statistik, 2000

22 Mikkelsen A, Petersen R, Rasmussen K, et al. Klorerede opløsningsmidler-et arbejdsmiliøproblem [Chlorinated solvents - an occupational health problem]. Copenhagen: Fremad, 1983.

23 Ingvorsen C. Skarpt miljø i tøirenserierne? [The environment in the dry cleaning shops?]. Nordisk Tidsskrift for Rensning, Farvning og Vask 1987;98(April): 12-15.

24 Anon. Perchlor-rensning i lukket kredsløb er en stor nyhed. [Tetrachloroethylene dry cleaning in closed-circuit-an item of news]. Nordisk Tidsskrift for rensning og vask 1978;89(Oct):21-2.

25 Hansen J, Sørensen S, Larsen R, et al. Renere teknologi i renseribranchen [Cleaner technology in the dry cleaning sector], Miliøprojekt 305. Copenhagen: Miliø- og Energiministeriet, 1995.

26 Jourdan M, Rentz O. Reduction of volatile organic compounds from dry cleaning facilities. Luxembourg: European Commission, 1994.

27 Miliøministeriets bekendtgørelse nr. 478 af 3. juli 1994 om forbud mod anvendelse af visse ozonlagsnedbrydende stoffer [Announcement of ban on using substances that deplete the ozone layer] 1994.

28 Sikkerhedsudvalget for Kemiske Industrier. Kemikalier og sikkerhed [Chemicals and safety]. Copenhagen: Teknisk Forlag, 1973.

29 Arbejdstilsynet. Grænseværdier for stoffer og materialer [Expsoure limits for substances and materials]. Copenhagen: Arbejdstilsynet, 2002.

30 Beretning om Arbeidstilsynets virksomhed $i$ arret 1962 [Annual report from the Labor Inspection 1962]. Copenhagen: Direktoratet for Arbejdstilsynet, 1963.

31 Korn J. [How many more? Perchlorate poisoning after dry-cleaning]. Ugeskr Laeger 1977; 139:303-4.

32 Symanski E, Kupper LL, Rappaport SM. Comprehensive evaluation of longterm trends in occupational exposure: Part 1. Description of the database. Occup Environ Med 1998;55:300-9.

33 European Commission. Technical and economic aspects of water pollution abatement measures for discharges from dry cleaning firms. Luxembourg: Direction Générale Envioronnement, Securite nucleaire et protection civile, 1994.

34 Mundt KA, Birk T, Burch MT. Critical review of the epidemiological literature on occupational exposure to perchloroethylene and cancer. Int Arch Occup Environ Health 2003;76:473-91.

35 Anon. Miløøstyrelsen vil frafalde forbudskrav, hvis forsvarlig teknisk løsning kan findes [The Danish Environmental protection Agency withdraws from prohibition if it is possible to find a safe technical solution]. Nordisk Tidsskrift for rensning og vask 1977;88(7):5-17.

36 Occupational Safety \& Health Administration. http://www.osha.gov/dts/ chemicalsampling/data/CH_260500.html, 2004.

37 Guenel P, Breum NO, Lynge E. Exposure to silica dust in the Danish stone industry. Scand J Work Environ Health 1989;15:147-53.

38 Jensen AA, Breum NO, Bacher J, et al. Occupational exposures to styrene in Denmark 1955-88. Am J Ind Med 1990;17:593-606.

39 Danmarks Statistik. Momsregistrerede virksomheder 1970. Bestand og Bruttobevægelsen [VAT-registered companies in 1970: Stock and gross changes], Stats Efterretninger 1973;65:645-8. 